\title{
The New ZEALAND CIVIL UNION ACT: NeW CHALlENGES FOR PRIVATE INTERNATIONAL LAW
}

\author{
Joanna Campbell
}

This article discusses private international law issues which arise as a result of the Civil Union Act 2004, which came into force in 2005. The author first discusses what kind of recognition New Zealand may extend to foreign unions, including both civil union type relationships and same sex marriages. This discussion considers recognition under the Civil Unions (Recognised Overseas Relationships) Regulations 2005, recognition as marriage and other possible avenues of recognition. This includes a consideration of currently recognised and unrecognised relationships, and the desirability of the current approach. It also includes a discussion of the issues surrounding the recognition of these types of relationships generally; for example, validity, status and public policy. The author then considers what kind of recognition the New Zealand civil union may receive in foreign jurisdictions.

\section{INTRODUCTION}

The enactment of the Civil Union Act 2004 and its coming into force in 2005 has given rise to much public debate. The Act also gives rise to less widely discussed issues in the area of private international law. Around the world various forms of recognition for domestic partnership have emerged. ${ }^{1}$ Many European countries, including the United Kingdom, have legislation similar to the New Zealand Civil Union Act 2004 which allows partners of the same or different sex to register their relationship. Other countries have made the more controversial move of amending their marriage laws to allow couples of the same sex to marry in the same way as different sex couples: namely Belgium, the Netherlands, Spain and some jurisdictions in Canada and the United States. Still others have a more contractually based regime, of which the French Pacte Civile de Solidarité (PACS) is a good example.

* Submitted as part of the LLB(Hons) programme at Victoria University of Wellington.

1 For a useful table see Robert Wintemute "The Massachusetts Same-sex Marriage Case: Could Decisions from Canada, Europe and South Africa help the SJC?" (2004) 38 New Eng L Rev 505, 517. 
This article discusses issues concerning what recognition and status New Zealand will give to these various forms of domestic partnership and what kind of recognition foreign jurisdictions might extend to the New Zealand civil union. These are important issues both for couples intending to come to New Zealand and for New Zealanders travelling abroad.

Recognition in New Zealand could take any of the following forms: recognition of the relationship as a marriage, recognition as a civil union (which it seems can only be achieved by way of the Civil Union Act 2004), or as something else - most likely a contractual relationship. Alternatively, recognition could be given to status (for example, that of married or a civil union partner) under an individual's own law, but possibly only for some purposes. ${ }^{2}$

This article will firstly discuss recognition as a civil union under the Civil Unions (Recognised Overseas Relationships) Regulations 2005. Secondly, the discussion will move to the issues surrounding recognition of those relationships not recognised under the regulations, including both same sex marriage and civil union type relationships. Thirdly, some alternatives to recognition of relationships as marriages or civil unions will be suggested. Finally, recognition of the New Zealand civil union in overseas jurisdictions will be considered.

\section{RECOGNITION OF OVERSEAS RELATIONSHIPS AS CIVIL UNIONS}

Section 5 of the Civil Union Act 2004 states that in any other enactment a reference to a civil union means either a civil union entered into under the Act, or a relationship entered into overseas and of a type recognised by regulations made under section 35 . This means that in order for an overseas relationship to confer rights on parties under New Zealand law, the relationship must be included in regulations made under section 35 or be recognised in some other way. ${ }^{3}$

\section{A Power to make Regulations}

Section 35(1)(a) confers power on the Governor-General by Order in Council to make regulations prescribing the types of overseas relationships that are recognised in New Zealand as civil unions. In addition, section 35(2) provides that no regulations under section 35(1)(a) may be made unless the Minister of Justice is satisfied that the relationship fulfils a list of conditions. ${ }^{4}$ So

2 Martha Bailey "Same Sex Relationships Across Borders" (2004) 49 McGill Law Journal 1005, 1010.

3 As marriage (see Part III Recognition of Overseas Marriages) or as something else (see Part IV Other Possible Avenues of Recognition).

4 Section 35(2) of the Civil Union Act 2004 provides as follows:

No regulations under subsection (1)(a) that recognise a type of overseas relationship may be recognised unless the Minister of Justice is satisfied that that type of overseas relationship is established or recognised under the law of that other country or jurisdiction, and that the law of that country or jurisdiction-

(a) does not permit or recognise the relationship unless both parties to it are at least 16 years old; and

(b) does not permit or recognise the relationship if the parties are related as- 
the approach to recognition taken under the Act is that a relationship can only be recognised as a civil union if it is included in regulations. It may be so included if it meets the conditions under section 35(2) but it does not have to be. This is essentially a listing approach with the prerequisite of meeting certain criteria: a minimum age of 16; a prohibited degree of consanguinity; consent; termination only by death or dissolution; and a requirement that it be monogamous. The advantage of this approach is that it creates certainty as to which types of relationship will be recognised as civil unions at any one time. The disadvantage is that there may not be consistency, as the Minister is not required to recognise all relationships meeting the criteria.

\section{B Currently Recognised Relationships}

Very few relationships have been recognised under the Civil Unions (Recognised Overseas Relationships) Regulations 2005 (Regulations). At 20 August 2005 only five types of relationship were recognised. These were the Finnish registered partnership, the German life partnership, the United Kingdom's civil partnership, and two from the United States: the domestic partnership of New Jersey and the civil union of Vermont. ${ }^{5}$

These relationships have all been deemed to meet the section 35(2) criteria. They all meet the age requirement that both parties are at least 16 years old or if a party is under 18 that the relationship be entered into with the consent of that person's guardians. ${ }^{6}$ All of the recognised relationships, except for the United Kingdom civil partnership, require the parties to be over $18 .^{7}$ In the case of the United Kingdom the parties must be over 16 and if under 18 must have guardian

(i) parent and child; or

(ii) siblings or half-siblings; or

(iii) grandparent and grandchild; and

(c) requires that the parties explicitly consent to entering into the relationship; and

(d) provides that the relationship ends only on the death of a party or by a judicial or other process that would be recognised by the courts of New Zealand as a dissolution; and

(e) requires that, during the relationship, the parties may not enter into that sort of relationship with anyone else, and may not marry anyone else.

5 Civil Unions (Recognised Overseas Relationships) Regulations 2005, reg 3.

6 Civil Union Act 2004, ss 35(2)(a) and 5(b)(ii).

7 Act on Registered Partnerships 2001 (Finland), s 1; Civil Unions Records and Licenses 18 VSA § 5163(a)(1); Domestic Partnership Act NJSA 26:8A-4(b)(7); In Germany, one cannot be validly contracted with a person who is a juvenile (under 18): Life Partnership Act 2001 (Germany), s 1(2)(1) and Civil Code (Germany), s 2 . 
consent. ${ }^{8}$ It is interesting that a New Zealand marriage would not meet this criterion; a marriage is not void if the parties were under 16 and did not have consent. ${ }^{9}$

They also meet the second criterion that the parties not be related as parent and child, siblings or half siblings, or grandparent and grandchild. ${ }^{10}$ The recognised types of relationships all have prohibited degrees of consanguinity and affinity. ${ }^{11}$ The German, UK and Finnish legislation clearly prohibit all of the listed familial relationships. ${ }^{12}$ The others raise some questions as to half siblings. In Vermont the wording of the Act is sister and brother and there is nothing in the Act to clarify whether this includes half siblings. ${ }^{13}$ In New Jersey a domestic partnership may not be entered into by persons who are related up to the fourth degree of consanguinity. ${ }^{14}$ However, this is likely to include half siblings, especially considering the prohibition of marriages of half siblings. ${ }^{15}$

The consent requirement is less clear in the recognised relationships. ${ }^{16}$ In the United Kingdom, the relationship is voidable if either party did not validly consent. ${ }^{17}$ Under German law, the relationship cannot be validly concluded if the parties do not want to undertake the required obligations. ${ }^{18}$ Finland only requires that the partnership not be registered if a partner cannot understand the significance of the matter. ${ }^{19}$ The law in New Jersey requires parties to execute and file an affidavit of domestic partnership. ${ }^{20}$ This must set forth, among other things, that the parties wish to enter into a domestic partnership with each other. ${ }^{21}$ Vermont has a requirement similar to

8 Civil Partnerships Act 2004 (UK) ss 3-4.

9 Marriage Act 1955, s 17.

10 Civil Union Act 2004, s 35(2)(b).

11 Act on Registered Partnerships 2001 (Finland), s 1(2); Act Relating to Civil Unions 15 VSA § 1203; Life Partnership Act 2001 (Germany), s 1(2)(2); Civil Partnerships Act 2004 (UK) 1st sch; Domestic Partnership Act NJSA 26:8A-4(b)(4).

12 Life Partnership Act 2001 (Germany), s 1(2); Civil Partnership Act 2004 (UK), s 3(1)(d); Act on Registered Partnerships 2001 (Finland), s 2(2); Marriage Act 1929 (Finland), s 7.

13 Act Relating to Civil Unions 15 VSA $§ 1203$.

14 Domestic Partnership Act NJSA 26:8A-4(4).

15 Marriage Act NJSA § 37:1-1.

16 Civil Union Act 2004, s 35(2)(c).

17 Civil Partnerships Act 2004 (UK), s 50(1)(a).

18 Life Partnership Act 2001 (Germany), s 1(2)(4). See also Life Partnership Act 2001 (Germany), s 1: parties "make a reciprocal declaration that they intend to lead a lifelong partnership with each other". The obligations are set out in section 2 of the Act.

19 Act on Registered Partnerships 2001 (Finland), s 4(2).

20 Domestic Partnership Act NJSA § 26:8A-4(a). 
Finland in that a civil union licence may not be issued if a party is non compos mentis. ${ }^{22}$ Comparing this to the requirement under section 14(2)(b) of the New Zealand Civil Union Act 2004 that the parties make a clear statement that they are freely joining in a civil union with each other, many of the recognised relationships do not as clearly require the parties' consent to be expressed. Though the section does not require the foreign law to ask for such an expression - it only requires that the law not permit or recognise a relationship where the parties do not explicitly consent - some kind of proof of the consent may be expected.

All the relationships clearly meet the final two requirements: that the law provides that the relationship end only on death or by a judicial or other process that would be recognised by the courts of New Zealand as a valid dissolution, ${ }^{23}$ and that the relationship is required to be monogamous. $^{24}$

In addition to the relationships already recognised, there is currently a Bill on civil partnerships before the Irish Parliament. The Bill requires parties entering into a civil partnership to be aged 18 years or over. ${ }^{25}$ It prohibits civil partnerships between parent and child, grandparent and grandchild, and siblings of the half or whole blood. ${ }^{26}$ The partnership is void if the parties do not validly consent. ${ }^{27}$ The relationship is terminated only by death, dissolution or annulment, ${ }^{28}$ and it is required to be monogamous. ${ }^{29}$ Therefore, this relationship would meet all the requirements and is able to be recognised under the regulations. It would need to be so recognised to be afforded recognition as a civil union in New Zealand.

21 Domestic Partnership Act NJSA § 26:8A-3.

22 Civil Union Records and Licenses 18 VSA § 5163(a)(1).

23 Family Proceedings Act 1980, s 44 sets out when New Zealand will recognise an order of dissolution. It is unclear whether the Civil Union Act 2004 is referring to valid dissolution in the sense that the dissolution would be recognised under this section or if it is wider than that. As to dissolution of the partnership: Act on Registered Partnerships 2001 (Finland), s 7 (same dissolution process as marriage); Act Relating to Civil Unions 15 VSA $§ 1206$ (same as marriage); Domestic Partnership Act NJSA § 26:8A-10 (termination under the jurisdiction of the Superior Court); Civil Partnership Act (UK) 2004, s 1(3); Life Partnership Act 2001 (Germany), s 15 (can be dissolved by court order); Life Partnership Act 2001 (Germany), s1 (there can be no time limit so it must be until death)

24 Act on Registered Partnerships 2001 (Finland), s 2(1); Act Relating to Civil Unions 15 VSA $§ 1202(1)$; Domestic Partnership Act NJSA§ 26:8A 4(b)(3); Life Partnership Act 2001 (Germany), s 1(2)(1); Civil Partnership Act 2004 (UK), s 3.

25 Civil Partnership Bill 2004 (Ireland), cl 3.

26 Civil Partnership Bill 2004 (Ireland), cl 3(2)(b) and sch.

27 Civil Partnership Bill 2004 (Ireland), cl 12.

28 Civil Partnership Bill 2004 (Ireland), cl 3(3).

29 Civil Partnership Bill 2004 (Ireland), cl 3(2)(a). 
Another relationship that is close to meeting the requirements is the French PACS. The PACS has less state intervention than the civil union and the other European relationships. The PACS requires parties to be of age (over eighteen). ${ }^{30}$ It will be void if entered into between ascendants or descendants or between collaterals to the third degree. ${ }^{31}$ It also requires the relationship to be monogamous. ${ }^{32}$ As it is a contract, it requires explicit consent to be binding. There is an issue as to dissolution and whether the process of dissolution is one recognised under New Zealand law: the parties may terminate the PACS by filing a joint written declaration, ${ }^{33}$ or the relationship can be dissolved by the marriage of one of the parties. ${ }^{34}$ The joint declaration is not dissimilar to the approach to dissolution of marriage in New Zealand so is unlikely to be a problem. ${ }^{35}$ However, because of issues of dissolution by marriage, the PACS may not be recognised. Although it is conceptually a very different type of relationship to the New Zealand civil union, it is not far from meeting the New Zealand criteria for recognition.

\section{Efficacy of the Criteria}

There are many relationships similar to the New Zealand civil union which are not recognised under the current regulations, mainly because of issues as to half siblings in relation to section 35(2)(b)(ii) and issues with the age requirement. ${ }^{36}$ As so few relationships can be recognised under the current criteria, the efficacy of the criteria needs to be considered. Is it desirable to recognise so few overseas relationships? The main issues for the European relationships are the approach taken to age and siblings related by the half blood. Thus, an option for reform would be to say that these relationships could be recognised so long as the parties were in fact over 16 when entering into the relationship and not related by the half blood, and if these conditions were not factually fulfilled the relationship would not be recognised in New Zealand. Alternatively, an approach similar to the external or international public policy approach could have been taken: New Zealand will not allow this within its borders but will recognise these relationships if validly concluded elsewhere. ${ }^{37}$ This, however, is not the approach the New Zealand legislature has chosen to take and so is not possible under the current legislation.

30 French Civil Code, title XII, ch 1, art 515-1. See French Civil Code, title X, ch 1, art 388, for the requirement to be over eighteen.

31 French Civil Code, title XII, ch 1, art 515-2(1).

32 French Civil Code, title XII, ch 1, art 515-2(2); 515-2(3).

33 French Civil Code, title XII, ch 1, art 515-7.

34 French Civil Code, title XII, ch 1, art 515-7.

35 Family Proceedings Act 1980, s 37. Parties can file a joint application for dissolution.

36 See Part III Recognition of Overseas Marriages.

37 See Part III D Exclusion by public policy. 
The legal effects of the relationship are important - perhaps the most important factor to those entering into them. So it is of note that the legal effects of the relationship do not feature in the section 35(2) criteria. Some of the overseas legislation simply confers rights that are identical to those of married couples, or essentially the same with some exclusions. ${ }^{38}$ Others list the rights and obligation of partners, which are similar to those of married couples. Another approach is to amend various relevant statutes, which New Zealand has done. ${ }^{39}$ Most, but not all, of the recognised relationships do not allow partners to adopt children. ${ }^{40}$

There is perhaps an additional element in that all the relationships currently recognised are for same-sex couples only. This may simply be indicative of the internationally popular approach. However, if New Zealand legislators wanted to exclude marriages they could add an additional criterion that the relationship only be available to parties of the same sex. This approach is unlikely as the New Zealand relationship is open to different sex partners, and therefore to do so may raise discrimination issues.

In practice, the listing approach is not ideal as the Regulations will require constant updating in order to keep up with the rapidly increasing number of jurisdictions legislating for recognition of domestic partnerships in alternative ways to marriage. In this respect, a criteria based approach leaving interpretation of the criteria to the courts may be preferable. There are also concerns for consistency in that the Minster may, not must, recognise relationships meeting the section 35(2) criteria. However, there is the advantage of certainty as to which relationships will be recognised as civil unions and which will not. This is useful for people wishing to immigrate to New Zealand, as they can order their affairs accordingly.

A notable feature of the criteria is that they describe a relationship very similar to marriage. Many refer directly to the relevant marriage laws for significant sections of the legislation. Therefore, it would seem strange if most relationships called marriage in their country of origin would not meet the criteria. However, as noted above, not even a New Zealand marriage would meet the criteria. There is nothing in the Act to prevent relationships called marriages being recognised under the Regulations. Inclusion in the Regulations may be an alternative to recognition as marriage. ${ }^{41}$

A discussion of the rules relating to the recognition of marriage is a useful vehicle to consider the issues that arise when deciding to recognise any type of relationship, particularly the validity of

38 Act on Registered Partnerships 2001 (Finland), s 9 excludes paternity and adoption.

39 Civil Union Act 2004, ss 38-46. See also Relationships (Statutory References) Act 2005.

40 German law was amended in 2004 to allow adoption by a couple in a life partnership.

41 See Part III Recognition of Overseas Marriages. 
the relationship, the status it affords to the parties to it and public policy issues. It is also important in considering whether same sex marriages will be recognised in New Zealand.

\section{RECOGNITION OF OVERSEAS MARRIAGES}

\section{A Validity}

In order for a marriage formed outside New Zealand to be recognised in New Zealand it must be formally valid and the parties must have capacity. There are then issues as to the consequence of the union and public policy. The union must be formally valid according to the place it was celebrated, the lex loci celebrationis. ${ }^{42}$ This concerns matters surrounding the actual ceremony of the marriage. ${ }^{43}$ The parties must have had capacity to marry and capacity to marry each other. This generally is decided by the law of each party's domicile immediately prior to the marriage. ${ }^{44}$ Generally, if these first two requirements are met, the union will be a valid marriage according to New Zealand law. However, there is also a less frequently noted element: the consequence of the union must be a marriage as it is understood in New Zealand. In Cheni v Cheni the court said that if a marriage were for a term less than life it would not be a marriage whatever it were called by its local law. ${ }^{45}$ This is an example of the consequence of the relationship being such that it is not a marriage as recognised by the lex fori. The issue of the consequence of the relationship was also relevant in Lee $v$ Lau, where the Court had to decide whether it could exercise jurisdiction over a potentially polygamous union. ${ }^{46}$ There is also a possibility of refusing to recognise a foreign marriage on the grounds of public policy. ${ }^{47}$

Issues of capacity also arise in the recognition of relationships as civil unions. As noted above, the main issues are consanguinity, affinity and age. If parties are not of age then they do not have capacity to marry and if they are within the prohibited degrees of consanguinity or affinity then they do not have capacity to marry each other.

42 Patel v Patel (1982) 1 NZFLR 413 (HC); Ogden v Ogden [1908] P 46 (CA); See also The Laws of New Zealand (Butterworths, Wellington, 2006) Conflict of Laws: Choice of law, para 18 (last updated March 2006) <www.butterworthsonline.com>; Lawrence Collins (ed) Dicey and Morris on the Conflict of Laws (13 ed, Sweet and Maxwell, London, 2000) 651. PM North and JJ Fawcett (eds) Cheshire and North's Private International Law (12 ed, Butterworths, London, 1992) 572. In New Zealand this is confirmed by the Marriage Act 1955, s 3(2).

43 Patel v Patel, above n 42; see also The Laws of New Zealand, above n 42, vol 7 Conflict of Laws: Choice of law, 24, para 19; North and Fawcett, above $n 42$.

44 Sottomayer v de Barros (1879) 5 P 94; See also The Laws of New Zealand, above n 42, Conflict of Laws: Choice of law, para 27.

45 Cheni v Cheni [1962] 3 All ER 873, 877 (PDA Div) Sir Jocelyn Simon P.

46 Lee v Lau [1964] 2 All ER 248 (PDA Div). This case involved a marriage which provided the possibility for the husband to take tipsis (concubines) though he had not in fact done so.

47 See Part III D Exclusion by public policy. 
In order for relationships to be recognised as civil unions, the law governing that relationship must not allow parties to be under 16 , and if they are 16 or 17 , must require them to have consent of their guardians. Issues arise in regards to this requirement with the Danish registered partnership, the Norwegian registered partnership and the Icelandic registered partnership. Section 2 of the Danish Registered Partnership Act 1989, referring to part 1 of the Formation and Dissolution of Marriage Act, requires parties to be at least 18, or have the permission of their parents and the County Governor's Office. There is no requirement that the parties be over the age of 16 in order to get this consent. Similarly, Norwegian law says that parties under the age of 18 may not enter into a registered partnership without consent of "persons having parental responsibility and the permission of the County Governor", ${ }^{48}$ while the Icelandic registered partnership requires parties to be at least 18 or under 18 with the consent of the Minister of Justice. ${ }^{49}$ Due to the age requirement under section 35(2) of the Civil Union Act 2004, these relationships cannot be recognised as civil unions in New Zealand. This may seem strict as compared to the English case of Mohamed $v$ Knott, where a potentially polygamous marriage between a 13 year old girl and a 26 year old man was recognised as valid. ${ }^{50}$

Similarly, not to recognise civil union relationships because they may be available to siblings of the half blood seems strict considering the requirements on consanguinity have not been as strictly observed in relation to foreign marriages. For example, in Cheni $v$ Cheni a marriage between uncle and niece which was allowed by the parties' domicile was recognised even though it would not have been allowed by the law of the forum. ${ }^{51}$

The Swedish registered partnership is an example of a relationship which is not recognised because of an issue with half siblings. The Swedish law does not allow registered partnerships between persons related to each other in direct ascending or descending line. ${ }^{52}$ It does not allow registered partnerships between siblings of the whole blood, but siblings of the half blood may register a partnership with the permission of the government or an authorised government authority. ${ }^{53}$ The Danish, Norwegian and Icelandic partnerships have similar issues. ${ }^{54}$

48 Registered Partnership Act 1993 (Norway), s 2; Marriage Act 1991(Norway), s 1.

49 Recognised Partnership Law 1996 (Iceland), s 2; Law in Respect of Marriage 1993 (Iceland), s 7.

50 Mohamed v Knott [1969] 1 QB 1.

51 Cheni $v$ Cheni, above n 45, 879 Sir Jocelyn Simon P.

52 Registered Partnership Act 1994 (Sweden), Chapter 1, s 3.

53 Registered Partnership Act 1994 (Sweden), Chapter 1, s 3.

54 Registered Partnership Act 1989 (Denmark), s 2; Formation and Dissolution of Marriage Act (Denmark), s 6; Registered Partnership Act 1993 (Norway), s 2; Marriage Act 1991 (Norway), s 3; Recognised Partnership Law 1996 (Iceland), s 2; Law in Respect of Marriage 1993 (Iceland), s 9. 
Another issue related to validity is consent. Section 31 of the Family Proceedings Act 1980 and section 23 (1) of the Civil Union Act 2004 say that marriages and civil unions where capacity is governed by New Zealand law are void ab initio where there is an absence of consent. Under section 35(2) of the Civil Union Act 2004, a relationship cannot be recognised unless the law of the country under which it was established or recognised requires consent of the parties. There is an issue with consent in the Danish registered partnership, as the consent requirement is unclear. The Registered Partnership Act does not expressly require consent, but section 3(2) could be interpreted as requiring consent as it provides that "the provisions of Danish law relating to marriage and spouses shall apply similarly to registered partners." In section 20(2) of the Formation and Dissolution of Marriage Act, consent is required for marriage. So consent would be required if this provision of Danish marriage law were applied.

\section{B Status}

When a marriage is recognised as valid, the parties to it have the status of a married couple. Status in New Zealand is governed by the law of the domicile. ${ }^{55}$ The determination of status is governed by the law of the domicile but the consequences of that status are decided by the lex fori. ${ }^{56}$ If there are no consequences of an individual's status it does not mean that person no longer has that status, it only means that while they are in New Zealand their capacity and rights are not affected by it. In other words, the recognition of a status under the law of the domicile does not necessarily involve giving effect to the results of that status in New Zealand. ${ }^{57}$ For example, a child may have the status of being illegitimate by the law of his or her domicile but in New Zealand the law does not attach any consequence to that ${ }^{58}$ A person's status affects their capacity; for example, in New Zealand a married person has no capacity to marry another person. ${ }^{59}$ Also, the status may be recognised but only as to some of its incidents. ${ }^{60}$ It is stated in Dicey and Morris on the Conflict of Laws that "[t]he mere fact that a foreign status or relationship is unknown to English law is not a ground for refusing to recognise its incidents." ${ }^{61}$ This point was illustrated in Shahnaz v Rizwan

55 Thompson $v$ Thompson (1950) 51 SRNSW 102, 103 Sugerman J; B D Inglis Conflict of laws (Sweet \& Maxwell (NZ) Ltd, Wellington, 1959) 109. It can also be governed by nationality: $R v$ Brentwood Superintendent Registrar of Marriages [1968] 2 QB 956, 967 Sachs LJ. Status is not governed by nationality in New Zealand.

56 Thompson $v$ Thompson, above n 55; Inglis, above n 55, 114.

57 Inglis, above n 55, 109.

58 Status of Children Act 1969, s 3.

59 Inglis, above $\mathrm{n} 55,109$. In the discussion of the distinction between capacity and status, and specifically whether status gives rise to capacity or capacity gives rise to status, Inglis concludes that status gives rise to capacity.

60 Bailey, above n 2, 1010.

61 Collins, above n $42,86$. 
where it was said that a polygamous marriage does give rise to a change in status, ${ }^{62}$ but also that the Court would not recognise some of the rights conferred by that status - namely the right to enforce marital rights and obligations. ${ }^{63}$

If same sex marriages are not recognised by New Zealand law, problems arise as to the status of the parties to them. There are also issues as to the status of those persons in any form of registered partnership not recognised under Regulations. ${ }^{64}$ If a person is not married it seems they would have to be unmarried; there is no middle status: "when we speak of status we mean only a distinct category recognised by law." 65 This is illustrated by Ford $v$ Ford where it was said that a judicial separation does not change the status of an individual, it merely alters the incidents of that person's status. ${ }^{66}$ This meant that the parties to that marriage were still married; the separation had merely altered some of the obligations they had towards each other.

If a marriage or civil union ${ }^{67}$ is not recognised and an individual is given the status of a single person, does this mean they will be able to marry or enter a civil union with another person in New Zealand? Policy would dictate that they should not be able to as there is a parliamentary intention that relationships in the nature of marriage be monogamous. ${ }^{68}$ This is in contrast to the definition of marriage in section 2 of the Family Proceedings Act 1980:

"Marriage" includes a union in the nature of marriage that-

(a) Is entered into outside New Zealand; and

(b) Is at any time polygamous, -

where the law of the country in which each of the parties is domiciled at the time of the union then permits polygamy.

62 Shahnaz v Rizwan [1965] 1 QB 390, 396 Winn J.

63 Shahnaz v Rizwan, above n 62, 397 Winn J.

64 See Part II Recognition of Overseas Relationships as Civil Unions.

65 Inglis, above n 55, 113, which includes a discussion of judicially separated women.

66 Ford v Ford [1947] 73 CLR 524, 529 (HCA) Latham CJ.

67 Or a similar relationship, which may be called a registered partnership, domestic partnership, civil partnership and so on.

68 Civil Union Act 2004, s 4(1)(c). 
However, this recognition of overseas polygamous marriages can be seen as reflecting the intention that marriages concluded in New Zealand be monogamous because recognition of a polygamous marriage prevents the parties to it concluding further marriages in New Zealand. ${ }^{69}$

\section{Same sex marriages}

The Civil Union Act 2004 has given rise to the question of which overseas domestic relationships will be recognised in New Zealand. The area of same sex marriage is, as was proven during debate over the Civil Union Act 2004, the most controversial one. At the emotional first reading of the Civil Union Bill the following comment was made by ACT member Stephen Franks MP: "...the sole true purpose to this Bill [is] to allow gay marriage. ${ }^{70}$

Thus far only the Netherlands, Belgium and Spain have allowed same sex couples to marry in the same way as different sex couples. ${ }^{71}$ As discussed above, normally if the requirements for formal validity and capacity are met the union will be afforded status as a marriage in New Zealand. However, questions arise as to whether the New Zealand courts would refuse to recognise such a union on public policy grounds or whether, considering the consequence of the union (that it may be entered into by parties of the same sex) it is, by New Zealand law, not a marriage at all. If a same sex marriage cannot be recognised as a marriage there is a possibility of it being recognised as a civil union if it meets the section $35(2)$ requirements. ${ }^{72}$

It is interesting to compare the structure of marriage in New Zealand, the Netherlands and Belgium. All require civil ceremonies in order to be valid. In the Netherlands and Belgium couples must first undertake a civil ceremony then they may, if they choose, have a religious ceremony. ${ }^{73}$ The same is true for New Zealand couples, who must gain a licence from the Registrar and later have it solemnised by a marriage celebrant, who can be a religious or non religious person. ${ }^{74}$

In the case of Quilter $v$ Attorney-General the Court of Appeal held that the Marriage Act 1955 requires a marriage to be between a man and a woman. ${ }^{75}$ It is therefore arguable that the courts

69 See Part II D Exclusion by public policy, specifically the discussion of domestic and international public policy. The crime of bigamy has been extended to civil unions: Crimes Act 1961, s 205.

70 (24 Jun 2004) 618 NZPD 13937.

71 There are also some states in Canada that allow same sex marriage: Bailey, above n 2, 1013. Same sex marriages were allowed in the United States, in Massachusetts: Bailey, above n 2, 1013. However, the position there is no longer certain due to the Marriage Protection Amendment which is before the legislature in the United States: Marriage Protection Amendment, $109^{\text {th }}$ Congress, SJ Res 1 and AJ Res 39.

72 See Part II Recognition of Overseas Relationships as Civil Unions.

73 Kees Waaldijk "Others May Follow: The Introduction of Marriage Quasi-Marriage and Semi-Marriage for Same Sex Couples in European Countries" (2004) 38 New Eng L Rev 569, 572-573 (Dutch); 581 (Belgian).

74 Marriage Act 1955, ss 24, 28 and 29.

75 Quilter v Attorney-General [1998] 1 NZLR 523 (CA) [Quilter]. 
would not recognise an overseas marriage between two persons of the same sex, as that is not a marriage as New Zealand law understands it. This goes to the consequence of the union. In deciding the consequence of a union the court will look to the law governing the marriage to see what the factual consequences are. It is then up to the lex fori to decide what this means. ${ }^{76}$ On the facts of Lee $v$ Lau this meant that the fact that a husband could take tipsis (concubines) was decided by Hong Kong law, but whether this made the marriage potentially polygamous was decided by English law. ${ }^{77}$ The Court in Quilter indicated that change to the understanding of marriage in New Zealand is something that is best left to Parliament. ${ }^{78}$ However, they were only considering the problem in a domestic context so it can be argued that this decision only relates to domestic marriage, especially considering the recognition of overseas polygamous marriages. ${ }^{79}$ But it can equally be argued that Parliament decided that the problem should be addressed by way of the Civil Union Act 2004, not through marriage legislation, and the courts should respect and give effect to that decision. During debate on the Civil Union Bill it was said that "the social, religious and traditional values associated with marriage will remain". ${ }^{80}$ By recognising foreign same sex marriages, the courts would arguably be going against Parliament's intention. There is evidence of a clear intention that marriage be reserved for different sex couples. In the Select Committee report it is said that "the Bill is intended to reflect Parliament's intention that marriage in New Zealand should remain available solely to a man and a woman." 81

The main issue in Quilter was human rights. Is it discriminatory, on grounds of sex or sexual orientation, to not allow same sex couples to marry? The issue was not clearly decided in Quilter as the court was able to reach its decision by saying that the Marriage Act 1955 clearly required marriage to be between a man and a woman. ${ }^{82}$ There was not a clear majority view on the discrimination question. Thomas $\mathrm{J}$ decided it was discriminatory, ${ }^{83}$ Keith $\mathrm{J}$ decided it was not, ${ }^{84}$

76 Lee v Lau, above n 46, 252 Cairns J.

77 Lee v Lau, above n 46.

78 Quilter, above n 75, 528 Gault J and 578 Tipping J.

79 Family Proceedings Act 1980, s 2. See also Part II D Exclusion by public policy.

80 (24 Jun 2004) 618 NZPD 13928.

81 Civil Union Bill, no 149-2 (Select Committee Report), 1. This seems to relate only to domestic marriage law. The issue of recognition of foreign relationships was certainly not the focus of the debate on the Civil Union Bill. However, the Select Committee did recommend amendments to allow recognition of overseas relationships. They stated that the approach taken was based on the United Kingdom's Civil Partnership Act 2004: Civil Union Bill, no 149-2 (Select Committee Report), 5-6.

82 Quilter, above $\mathrm{n} 75$.

83 Quilter, above n 75, 528 (CA) Thomas J.

84 Quilter, above n 75, 555 (CA) Keith J. 
Tipping $\mathrm{J}$ did not reach a final conclusion, ${ }^{85}$ Richardson $\mathrm{P}$ was not persuaded that it was discriminatory, ${ }^{86}$ while Gault $\mathrm{J}$ thought it was not discriminatory and that the real complaint was that same sex couples cannot gain the same rights and privileges as married people. ${ }^{87}$ So, overall, a majority expressed the view that denying same sex couples the right to marry was not discriminatory. The comment that there may be discrimination on the grounds of marital status, as same sex couples are not afforded the same rights as married couples, was not expanded upon by the court but has potential to be a very persuasive argument. ${ }^{88}$ This case, though it did not recognise the right of the couples to marry, was a catalyst for the introduction of the Civil Union Bill. ${ }^{89}$ There is still an argument to say that the courts should recognise same sex marriages on the grounds that not to do so would be discriminatory. The Civil Union Act 2004 tends to indicate that, at least in the view of the legislature, recognition of partnerships as civil unions may be enough to comply with obligations under the New Zealand Bill of Rights Act 1990 and the Human Rights Act 1993. However, there are issues for partnerships which cannot be recognised in this way. ${ }^{90}$ The Court noted various international responses to the discrimination problem. ${ }^{91}$

So there are human rights arguments for some form of recognition. There are also more practical policy arguments. These are similar to those raised for recognition of polygamous unions ${ }^{92}$ For example, if a union is valid where made and the parties order their family's affairs on that basis, not to recognise it could cause injustice. Consider an individual who is married according to their personal law and is therefore entitled to maintenance or property. This person then moves to New Zealand where the union is not recognised and the parties separate. One party may not be able to gain the benefits that the parties intended they should be able to. The problem used to be particularly obvious where there were issues of legitimacy of children. ${ }^{93} \mathrm{~A}$ child legitimate where born may be deemed illegitimate through denial of recognition of the parents' marriage. ${ }^{94}$ This point is made well in Dicey and Morris on the Conflict of Laws where it is said that "[i]t may be better to recognise it

85 See Part II Recognition of Overseas Relationships as Civil Unions.

91

Quilter, above n 75, 574 (CA) Tipping J.

Quilter, above n 75, 526 (CA) Richardson P.

Quilter, above n 75, 528 (CA) Gault J.

Quilter, above n 75, 528 (CA) Gault J.

(24 Jun 2004) 618 NZPD 13944.

Quilter, above n 75, 548 (CA) Thomas J.

Collins, above $n$ 42, 83 .

In Re Goodmans Trusts (1881) 17 Ch 266 (CA); Collins, above n 42, 83.

The approach taken under the Civil Union Act 2004 is restrictive as to recognition of overseas partnerships.

While no longer an issue in New Zealand, it serves as a good illustration: Status of Children Act 1969, s 3. 
[the marriage] than to disturb settled family relationships."95 There are also international comity and reciprocity issues if New Zealand wants relationships formed under the Civil Union Act 2004 to be recognised overseas.

Quilter was a case with no international element. In Lee $v$ Lau, an English case concerning a potentially polygamous marriage concluded in Hong Kong, the court said that "what English law normally understands by "marriage" is ... the voluntary union of a man and a woman to the exclusion of all others." 96 This would tend to suggest that same sex marriage would not be recognised. However, the attitude of the courts and the legislature is changing. ${ }^{97}$ In regard to the 'exclusion of all others' element of the definition, the legislature has provided that at least for the purposes of the Family Proceedings Act 1980, marriage can include a polygamous union if at the time of the union such a union was permitted by the law of the parties' respective domiciles. ${ }^{98}$ Also, in the case of Cheni $v$ Cheni it was noted that polygamous marriage can now be recognised by English courts for most purposes. ${ }^{99}$ So it is clear that such a marriage will be recognised unless there is some strong reason to the contrary. The argument is that policy dictates that it is necessary to give effect to the relationship, especially where rights of third parties are involved.

The distinction between an actually and a potentially polygamous union is that a union is actually polygamous if there are in fact more than two parties to it; a union is merely potentially polygamous if the law governing the marriage permits one or both parties to have more than one spouse but neither party has in fact taken another spouse. Both types have been recognised for many purposes. ${ }^{100}$

There is an analogy to be drawn between recognition of actually or potentially polygamous unions and same sex unions in that neither fulfils the definition of marriage as New Zealand law understands it. So there is an argument that if the courts are willing to recognise a union which is not to the exclusion of all others, they should be willing to recognise one which is not between a man and a woman. The relaxation of the rules for recognition of polygamous marriages indicates a judicial and legislative tolerance for foreign unions that could be extended to same sex marriages.

95 Collins, above $\mathrm{n} 42,83$.

96 Lee $v$ Lau, above n 46, 252 Cairns J.

97 Attitudes are also changing regarding the "for life" element set out in Hyde v Hyde and Woodmansee (1866) LR 1 (PD) 130, 133. There is now 'no fault' divorce in New Zealand: Family Proceedings Act 1980, ss 37 and 39 .

98 Family Proceedings Act 1980, s 2.

99 Cheni v Cheni, above n 45, 879 Sir Jocelyn Simon P.

100 In Re Sehota [1978] 1 WLR 1506 (Ch), concerning an actually polygamous marriage; Shahnaz v Rizwan [1965] 1 QB 390, concerning a potentially polygamous marriage. See generally: North and Fawcett, above $n$ 42,621 . 
It is also interesting to note that apart from the name there are very few practical differences in New Zealand domestic law for those in de facto relationships, civil unions or marriages. All are treated equally in terms of property rights. ${ }^{101}$ Similarly upon death of a spouse or partner the relationships all receive equal treatment. ${ }^{102}$ There is a difference for de facto couples regarding social security. For example for the domestic purposes benefit, de facto partners are treated differently to those who are married or in a civil union. ${ }^{103}$

There is a further issue as to recognition of different sex marriages made in jurisdictions allowing same sex marriage. This is analogous to a potentially polygamous marriage, which is in the same category as an actually polygamous union. Both have been recognised for many purposes. Therefore, following Lee $v$ Lau, the nature and incidents of the union are to be decided according to the lex loci celebrationis. ${ }^{104}$ The nature of a marriage from, for example, Belgium, is that it may be concluded between two parties of the same sex. The union is therefore one which permits marriages other than between a man and a woman. If a similar approach is taken to such a relationship as that which has been taken to polygamous marriages, whether or not the marriage is actually between a same sex couple should not affect its recognition. If different sex but not same sex unions from the same jurisdiction were to be recognised there would again be an issue with discrimination on the grounds of sex or sexual orientation as arose in Quilter. Couples with an identical relationship except for the sex of the parties would be extended different rights under New Zealand law. This is very problematic from a Bill of Rights Act 1990 point of view as section 19 protects the right to freedom from discrimination on the grounds set out in the Human Rights Act 1993.

\section{Exclusion by public policy}

As with all questions of choice of law, there is the possibility of excluding foreign law on grounds of public policy. ${ }^{105}$ Similar arguments to those that were put forward against the Civil Union Bill are bound to be raised. An example is the discussion in Quilter about the ability of a couple to procreate. ${ }^{106}$ Additionally, it seems that one of Parliament's main reasons for enacting the Civil Union Act 2004 and not amending the Marriage Act 1955 was to reserve the institution of marriage solely for heterosexual couples. ${ }^{107}$

101 Property (Relationships) Act 1976.

102 Administration Act 1969, s 77; Property (Relationships) Act 1976, s10B. These provisions apply upon the death of a spouse or partner.

103 Social Security Act 1964, s 27B. But compare Social Security Act 1964, s 27C.

104 Lee v Lau, above n 46, 252 Cairns J.

105 Collins, above n 42, 81 .

106 Quilter, above n 75, 534 Thomas J.

107 Civil Union Bill, no 149-2 (Select Committee Report), 1. 
In this area it is important to note that there are different types of public policy. Firstly, there is internal public policy; what a country wants to happen within its borders. Secondly, there is international public policy. This is often used in the conflict of laws to mean that a country refuses to recognise a foreign law it believes is contrary to its public policy. This is the most discussed type in this area. International public policy is also used to say a foreign law may be recognised, although locally it is illegal. This is the flip side of the second type. It means that though something may not be valid if it is done domestically, it may be valid if it is done abroad and is valid where it was done. In other words, "not every rule of law which belongs to the 'ordre public interne' is necessarily part of the 'ordre public externe or international'."108

Polygamous marriages are an example of use of this last type. For example, a court will recognise a foreign polygamous marriage in order to provide for persons under succession law, ${ }^{109}$ but it will not allow persons to conclude a polygamous marriage within its own borders. In fact, to do so is a crime. ${ }^{110}$ So polygamy is contrary to domestic public policy but not to external or international public policy. In the area of same sex marriage the courts could use this latter type of public policy and say that same sex marriage is contrary to the public policy of New Zealand in that New Zealand does not allow it to happen within its borders, but it is not so contrary to public policy that the New Zealand courts will not recognise a same sex marriage validly concluded elsewhere. This is especially so given the rights extended to almost all types of adult domestic relationships, whether same or different sex, through de facto relationships and civil unions.

The courts have previously indicated they will not recognise, on the grounds of public policy, incapacity to marry for reasons such as race or religion. ${ }^{111}$ It is of note that these refusals of recognition are where a person is denied capacity contrary to their human rights. It is also notable that New Zealand law will recognise polygamous marriages for most purposes, even though their conclusion is a crime within New Zealand. This strengthens the argument for recognition of same sex marriages. As New Zealand provides a similar relationship in the Civil Union Act 2004, a same sex marriage is arguably more in conformity with New Zealand public policy than a polygamous marriage. Also, same sex couples have very similar rights to married couples. For example, the Property (Relationships) Act 1976 applies to same sex couples, de facto partners, civil union partners and married couples.

The Netherlands recognised that such problems might arise: "the question relating to the completely new legal phenomenon of marriage between persons of the same sex concerns the

108 JHC Morris (ed) Dicey and Morris on the Conflict of Laws (10 ed, Stevens \& Sons Ltd, London, 1980$) 804$.

109 Bamgbose v Daniel [1955] AC 107 (PC).

110 Crimes Act 1961, ss 205-206.

111 For example, the inability of priests and monks to marry; Sottomayer v de Barros (1879) 5 P 94, 104. 
interpretation of the notion of public order to be expected in other countries." ${ }^{112}$ Also, it is later noted that "as a result of this spouses of the same sex may encounter various practical and legal problems abroad."113

Illustrating these problems is the issue of whether parties to a foreign same sex marriage could get a declaration that they were married under the Family Proceedings Act 1980. ${ }^{114}$ The court could follow a similar approach to Hassan v Hassan where Somers J said: "I do not think it is necessary for me to determine whether the marriage was formally and essentially valid." ${ }^{115}$ Instead it was simply decided that whatever there was had been dissolved. ${ }^{116}$ Hassan $v$ Hassan was a case involving a couple seeking dissolution of a potentially polygamous marriage. The problem for polygamous marriages was solved by the definition of marriage in the Family Proceedings Act 1980. ${ }^{117}$ But Hassan $v$ Hassan shows a willingness to recognise marriages that could be extended to same sex marriages. Whether a same sex married couple could get a declaration would depend on the approach taken, but Hassan $v$ Hassan tends to indicate that they would be able to.

Because of public objection and likely political fallout, the courts are unlikely to recognise a foreign same sex marriage as a marriage outright. However, because of human rights objections such as those raised in Quilter, it may be desirable to recognise some rights of the couple. This could be done by recognising some incidents of the relationship, as is done for polygamous marriages, ${ }^{118}$ or by giving them the same status as civil union partners. However, because of the way the Civil Union Act 2004 has been structured, it is very difficult to see how it would be possible to recognise such persons as civil union partners. ${ }^{119}$

\section{OTHER POSSIBLE AVENUES OF RECOGNITION}

\section{A Contract}

An alternative avenue for recognition of domestic partnerships is through the private international law rules governing contracts. The relevant choice of law rule is that the contract is

112 Law on the Opening up of Marriage for Same Sex Partners (explanatory memoranda, Netherlands, 2000), para 5, translation by Kees Waadljidk <http://www.meijers.leidenuniv.nl/index> (last accessed 4 May 2006).

113 Law on the Opening up of Marriage for Same Sex Partners, above n 112, para 5.

114 Family Proceedings Act 1980, s 27.

115 Hassan v Hassan [1978] 1 NZLR 385, 389 (SC) Somers J.

116 Hassan v Hassan, above n 115, 391-393 Somers J.

117 Family Proceedings Act 1980, s 2.

118 Bailey, above n 2.

119 Civil Union Act 2004, s 5. 
governed by its proper law. ${ }^{120}$ This could apply particularly to relationships such as the French PACS, which is a kind of registered contract. ${ }^{121}$ There, the parties can decide on what to put in their registered contract, unlike the New Zealand civil union where the effects of registering a relationship are set out in statute. Though parties to such a contract would not be recognised as civil union partners under section 5 of the Civil Union Act 2004, there seems to be no reason why their contractual rights towards each other would not be recognised. Thus, the contractual relationship may be of assistance when the issue is between the parties to a civil union, but it will not be helpful if the issue involves a third party. ${ }^{122}$ For example, contract will be of assistance if the dispute is about property division on separation, but it will not be of assistance if the couple is seeking to take advantage of state social security benefits given to civil union partners.

Section 40A of the Property Law Act 1952 states that as regards property, no contract between a couple living as husband and wife shall be void on grounds of public policy or illegal consideration. This section solves the historical problem of refusal to recognise cohabitation contracts as immoral, at least as regards property rights. The section does not seem to include same sex couples, as it begins: "[n]o agreement between a man and a woman... ." While this is of much less consequence because of the Property (Relationships) Act 1976, which extends property rights to de facto couples, it may still be useful for those whose relationships are of short duration. In addition, those in relationships of short duration may be able to rely on a constructive trust. ${ }^{123}$

\section{B De Facto Relationship}

There is also the possibility that overseas civil union partners would qualify as de facto partners. The definition of de facto partner is a person who is in a de facto relationship with another person. ${ }^{124} \mathrm{~A}$ de facto relationship is defined as a relationship between two persons over 18 living together as a couple and who are not married or in a civil union with each other. ${ }^{125}$ There are various circumstances to be taken into account when deciding whether the parties are living together as a couple. ${ }^{126}$ If a couple in a foreign civil union could fulfil this definition, ${ }^{127}$ this would afford them some of the same rights as civil union partners, particularly succession and property rights, as

120 Amin Rasheed Shipping Corp v Kuwait Insurance Co [1983] 1 All ER 873 (HL).

121 French Civil Code, title XII, ch 1.

122 Bailey, above n 2, 1027.

123 Lankow v Rose [1995] 1 NZLR 277 (CA).

124 Property (Relationships) Act 1976, s 2C.

125 Property (Relationships) Act 1976, s 2D(1).

126 Property (Relationships) Act 1976, s 2D(2)

127 Civil Union Act 2004, s 5. If the relationship is not listed under the Regulations it is not a civil union in the Property (Relationships) Act 1976 or any other enactment. 
de facto partners are afforded rights under the Property (Relationships) Act 1976. There is no requirement for recognition as a de facto couple that the couple have been living in New Zealand.

\section{Universality Principle}

Another possibility is recognition of the status of an individual under what Martha Bailey calls the universality principle, and recognition of some of the incidents of that status. ${ }^{128}$ In describing the universality principle, Bailey says that "status validly acquired under a party's personal law will be recognised everywhere."129 This is possible because even if a status is unknown to New Zealand law, the incidents of that status could still be recognised in New Zealand. ${ }^{130}$ As New Zealand has a civil union, such status exists in New Zealand, but it is arguable that section 5 of the Civil Union Act 2004 prevents recognition in this way. This avenue of recognition is more relevant to marriages, as discussed earlier.

\section{Private International Law Rules}

New Zealand could also develop private international law rules specifically for civil unions, by analogy to marriage or otherwise, as has been done in some provinces in Canada. ${ }^{131}$ However, the approach taken in the Regulations indicates that this will not be done. The intention is to recognise only those relationships that are listed in the Regulations.

\section{RECOGNITION OF THE NEW ZEALAND CIVIL UNION OVERSEAS}

It is not possible to determine exactly what kind of recognition the New Zealand civil union will receive overseas. Every country will have a different approach to recognition of such unions. However, it is possible and useful to consider some approaches that have been taken to similar partnerships in order to illustrate what may happen and the issues that arise.

The New Zealand civil union is different from many overseas registered partnerships in that it is available to both same and different sex couples. Therefore, there is an additional question as to whether countries which will not recognise same sex civil unions will also refuse to recognise different sex civil unions. It is also questionable whether countries that only permit same sex couples to enter civil unions will recognise a New Zealand different sex civil union.

One approach that could be taken is to simply recognise a union as valid where made. This is the approach taken in Finland. Section 12 of the Act on Registered Partnership provides that "[t]he registered partnership of two persons of the same sex that has been registered in a foreign state shall

\footnotetext{
128 Bailey, above n 2, 1010.

129 Bailey, above n 2, 1010.

130 Collins, above n 42, 86.

131 Bailey, above n 2, 1021.
} 
be valid in Finland if it was valid in the state where it was registered." The New Zealand civil union would be likely to fall under this section, depending on the definition of registered partnership, but it is similar to the Finnish partnership so it is likely to be included. There is an issue for different sex civil unions as the section mentions "two persons of the same sex". This seems to exclude a registered partnership between persons of different sexes.

The United Kingdom has taken a similar approach to that taken in New Zealand. ${ }^{132}$ Section 212 of the Civil Partnership Act 2004 gives a definition of an overseas relationship. An overseas relationship can be either a relationship specified in Schedule 20, like New Zealand's listing approach in the Regulations, or a relationship meeting some general conditions. Overseas relationships are to be treated as civil partnerships as long as the partnership is formally valid and the parties had capacity to enter into it under the relevant law. ${ }^{133}$ The relevant law is defined as "the law of the country or territory where the relationship is registered (including its rules of private international law)". ${ }^{134}$ However, an overseas relationship can only be recognised as a civil partnership if the parties to it are of the same sex. ${ }^{135}$ The New Zealand civil union is not one of the relationships listed in Schedule 20. This could be because the New Zealand Civil Union Act 2004 had not been passed at the time. It seems, however, that the New Zealand civil union will meet the general requirements anyway. ${ }^{136}$ The major issue then is for different sex civil unions, which it seems, considering the language of the English statute, are not able to be recognised as civil partnerships. Different sex civil unions would then have to be recognised in some other way.

Another option for recognition of civil unions is that taken in New York. In the case of Langlan $v$ St Vincent's Hospital, ${ }^{137}$ the Court applied the state's choice of law rule applicable to marriage to a Vermont Civil Union. ${ }^{138}$ The civil union in question was a same sex civil union. The Court took the view that a civil union, though it is not called a marriage, is so similar that it is in effect a marriage. ${ }^{139}$ As the New Zealand civil union is also very similar to a marriage it could also be given recognition in this way in New York. However, it is unclear whether New York will extend such

\footnotetext{
132 See generally David McClean and Kisch Beevers (eds) The Conflict of Laws by the Late JHC Morris (6 ed, Sweet \& Maxwell, London, 2005) 212.

133 Civil Partnership Act 2004 (UK), s 215.

134 Civil Partnership Act 2004 (UK), s 212(2).

135 Civil Partnership Act 2004 (UK), s 216 and see also s 212(1)(b)(i).

136 Civil Partnership Act 2004 (UK), s 214.

137 Langlan v St Vincent's Hospital (2003) 765 NYS 2d 411.

138 Langlan v St Vincent's Hospital, above n 137; Bailey, above n 2, 1023.

139 Langlan v St Vincent's Hospital, above n 137; Bailey, above n 2, 1024.
} 
recognition to civil unions for all purposes as Langlan $v$ St Vincent's Hospital was about the meaning of spouse in a wrongful death statute. ${ }^{140}$

Quite the opposite approach to that of the New York courts has been taken in other parts of the United States. In the United States, marriage and divorce are matters of state jurisdiction. ${ }^{141}$ There is a federal statute, the Defence of Marriage Act, which defines marriage as a union between one man and one woman. This statute attempts to get around the requirement that States give full faith and credit to the laws of other States. It provides that no State is required to recognise any law which gives rights to same sex couples that are similar to marriage. ${ }^{142}$ The constitutionality of this has been called into question. ${ }^{143}$ Some states have also enacted similar laws to avoid having to recognise same sex marriages or civil unions. ${ }^{144}$ For example, the law in Texas provides that a civil union is any relationship other than marriage "which is intended as an alternative to marriage or applies primarily to cohabitating persons and grants to the parties of the relationship legal protections, benefits or responsibilities granted to the spouses of a marriage." 145 The New Zealand civil union would clearly come under this description. The Texas law then states that a marriage between persons of the same sex or a civil union is contrary to the state's public policy and is void. ${ }^{146}$ There is no requirement that the civil union be between persons of the same sex. Therefore it seems, as a matter of statutory interpretation, that a different sex civil union could not be recognised in Texas. This means that a different sex couple would need to marry in order to have their rights recognised in Texas.

The Australian position on recognition of foreign civil unions is unclear. Nygh has discussed it with reference to the Swedish registered partnership. He says "it is unlikely that the relationship will be recognised as marriage" as it does not purport to be marriage and because marriage in Australia is still defined as the union of one man and one woman. ${ }^{147} \mathrm{He}$ compares this to polygamous marriage where the common law allowed limited recognition. ${ }^{148}$ Australia has recently amended its law by adding to the Marriage Act 1961 a definition of marriage which is "the union of a man and a woman

140 Langlan v St Vincent's Hospital, above n 137; Bailey, above n 2, 1024.

141 Bailey, above n 2, 1009.

142 Bailey, above n 2, 1008.

143 Bailey, above n 2, 1008.

144 Bailey, above n 2, 1015-1016.

145 Texas Family Code, title 1 § 6:204; Bailey, above n 2, 1016.

146 Texas Family Code, title 1 § 6:204.

147 Hon Dr Peter Nygh "Homosexual Partnerships in Sweden" (1997) 11 AJFL 11, 12.

148 Nygh, above n 147, 12. 
to the exclusion of all others, voluntarily entered into for life."149 Section 88EA of the Marriage Act 1961, which was added by the same amending Act (the Marriage Amendment Act 2004), says that unions between parties of the same sex solemnised in a foreign country are not marriages. Though this section applies only to recognition of marriages, it may indicate an unwillingness to recognise any same sex relationships, at least at the federal level. However, some states in Australia have enacted laws extending marriage-like rights to same sex couples. ${ }^{150}$

Some states in Canada have set out private international law rules for recognition of civil unions specifically. For example, the Quebec Civil Code provides that formal validity is governed by the law of the place of solemnisation. ${ }^{151}$ There are other approaches that may be taken. One is to recognise the civil union as a contractual relationship and enforce contractual rights. As discussed above, this is only effective for some purposes. Another is to extend some rights to the couple as a de facto couple, where such recognition is provided for by the law of that jurisdiction. For international recognition, this overview shows that different sex couples are better off to be married than in a civil union, as different sex civil unions seem unlikely to get recognition abroad, even when it seems likely that their same sex counterparts will.

\section{CONCLUSION}

There are many variations in form of domestic relationships and ways to recognise them across borders. This paper has given an overview of the kinds of relationship structures and of issues that arise regarding inward and outward recognition of relationships. This has become relevant to New Zealanders with the introduction of the Civil Union Act 2004.

Thus far there is no worldwide status of 'civil union partner' as there is for married persons. Therefore, individuals in civil unions or registered partnerships are at the mercy of each nation's private international law rules and notions of public policy. Those coming to New Zealand can only be certain of their status if they are listed in the Regulations or are a different sex married couple. Others have to rely on recognition as marriages or as contracts. As has been seen, the law on recognition of same sex marriages in New Zealand is uncertain, while contractual rights will only be of assistance to couples for some purposes. In order for there to be certainty and fairness towards

149 Marriage Act 1961 (Cth), s 5(1).

150 ACT (see for example Domestic Relationships Act 1994 (ACT), Administration and Probate (Amendment) Act 1996 (ACT), Family Provision (Amendment) Act 1996 (ACT), Legislation (Gay, Lesbian and Transgender) Amendment Act 2003 (ACT), Discrimination Amendment Act 2003 (ACT)); NSW (see for example Property (Relationships) Legislation Amendment Act 1999 (NSW)); Queensland (see for example Property Law Amendment Act 1999 (Qld), Discrimination Law Amendment Act 2002 (Qld)); Tasmania (see for example Relationships Act 2003, Relationships (Consequential Amendments) Act 2003); Victoria (see for example Statute Law Amendment (Relationships) Act 2001 (Vic)); Western Australia (see for example Acts Amendment (Lesbian and Gay Law Reform) Act 2002 (WA)).

151 Quebec Civil Code, bk 10, 10, title 2, ch 1, div 2, art 3090.1; Bailey, above n 2, 1022. 
parties to foreign relationships it is desirable that the rules about recognition of foreign marriages and civil unions are revisited. 